\title{
OPTIMALISASI PENYAMPAIAN MATERI PEMBELAJARAN SENI BUDAYA DAN PRAKARYA MELALUI PEMBELAJARAN TERPADU BERBASIS GPO
}

\author{
Pamela Mikaresti $^{1}$, Yeni Meylani ${ }^{2}$, dan Feby Elra Perdima ${ }^{3}$ \\ ${ }^{1}$ Program Studi PGSD, Universitas Terbuka \\ Email: pamela@ecampus.ut.ac.id \\ ${ }^{2}$ Jurusan Pendidikan Dasar, STIT Bengkulu Indonesia \\ Email: yenimeylani@gmail.com \\ ${ }^{3}$ Program Studi Pendidikan Olah Raga, Universitas Dehasen \\ Email: perdima.elra@gmail.com
}

\begin{abstract}
The learning materials of arts, culture and crafts (SBdP) are not delivered optimally by teachers of Al Khair Bengkulu Selatan Foundation that is caused by several factors. First, the teacher's factor. The delivery of the SBdP content has not accommodated student interest, has not maximally implemented creative cooperative learning, and has not created an interesting and pleasant atmosphere for students. Second, the student's factor. The child's interest in the method of art education, in learning the arts, both music, dance, drama and fine arts, the child feels bored because they do not find something interesting and fun. Third, the facilities and infrastructure in the school that have not been fulfilled to assist teachers in delivering SBdP learning materials, especially schools of Yasayan Al Khair Bengkulu Selatan. To overcome this problem, training was carried out for Al Khair Foundation teachers using training methods, which are 1) Community Development Model, involving teachers as the subject and object of the implementation of Lecturer Abdimas activities; 2) A persuasive approach, encouragement and support without coercion for teachers to take an active role; 3) Educative, a team approach through outreach, training and mentoring, in the context of exchanging knowledge and experiences as a feature of community empowerment. This training is useful for Al Khair Foundation teachers in increasing their knowledge related to information technology, skilled in accessing the Portal Guru Pintar Online (GPO), and optimizing their ability to deliver SBdP learning materials to students.

Keywords: optimization, cultural arts materials, integrated learning, GPO
\end{abstract}

\begin{abstract}
ABSTRAK
Kurang optimalnya penyampaian materi pembelajaran seni budaya dan prakarya (SBdP) oleh guru-guru Yayasan Al khair Bengkulu Selatan disebabkan oleh beberapa faktor yaitu guru, siswa dan sarana prasana sekolah. Pertama, dilihat faktor guru sebagai pendidik mengenai cara penyampaian materi muatan pembelajaran SBdP tersebut belum mengakomodir ketertarikan siswa, belum maksimal menerapkan pembelajaran kooperatif yang kreatif, dan belum menciptakan suasana yang menarik dan menyenangkan bagi siswa. Kedua, jika dilihat dari faktor siswa, minat anak terhadap metode pendidikan seni yang didapatkannya, dalam pembelajaran seni baik seni musik, seni tari, seni drama dan seni rupa, besar kemungkinan adalah anak merasa bosan karena ia tidak menemukan sesuatu yang menarik dan menyenangkan. Ketiga, dilihat dari sarana dan prasarana yang ada di sekolah yang belum terpenuhi guna membantu guru dalam menyampaikan materi pembelajaran SBdP khususnya sekolah dibawah naungan Yasayan Al Khair Bengkulu Selatan. Untuk mengatasi permasalahan tersebut, maka dilaksanakan pelatihan bagi guru-guru Yayasan Al Khair dengan menggunakan metode pelatihan yaitu 1)Model Community Development, yaitu melibatkan guru-guru secara langsung sebagai subyek dan obyek pelaksanaan kegiatan Abdimas Dosen; 2)Pendekatan persuasif, yaitu himbauan dan dukungan tanpa unsur paksaan bagi guru-guru untuk berperan aktif; 3)Edukatif, yaitu pendekatan tim melalui sosialisasi, pelatihan dan pendampingan, dalam rangka saling bertukar pengetahuan dan pengalaman sebagai ciri bentuk pemberdayaan masyarakat. Pelatihan ini bermanfaat bagi guru-guru Yayasan Al Khair dalam meningkatkan pengetahuannya terkait teknologi informasi, terampil mengakses informasi berbasis teknologi dalam hal ini adalah mengakses Portal Guru Pintar Online (GPO), serta mengoptimalkan kemampuannya menyampaikan materi pembelajaran SBdP pada siswa.
\end{abstract}

Kata kunci: optimalisasi, materi seni budaya, pembelajaran terpadu, GPO

\section{PENDAHULUAN}

Perkembangan ilmu pengetahuan dan teknologi saat ini mempermudah setiap orang memperoleh berbagai informasi dari seluruh penjuru dunia tanpa terkecuali. Pada masa ini setiap individu khususnya para pendidik dituntut untuk memiliki kecakapan atau prakarya baik hard skill maupun soft skill agar dapat memasuki ke dunia pekerjaan dan siap berkompetisi dengan negara lain. 
Prakarya yang harus dimiliki oleh setiap individu pada abad 21 menurut Trilling dan Fadel (2009) "the core subjects and interdisciplinary 21 st century themes are surrounded by three sets of skills most in demand in the 21st century: (i) learning and innovation skills, (ii) information, media and technology skills, (iii) life and career skills". Hal ini menunjukkan bahwa salah satu prakarya yang harus dimiliki oleh siswa maupun guru yaitu prakarya informasi, media, dan teknologi.

Media pembelajaran sangat penting guna membantu proses pembelajaran. Penggunaan media pembelajaran yang tepat akan mempermudah siswa menerima materi yang disampaikan oleh gurunya. Media pembelajaran yang efektif juga akan membantu guru memaksimalkan waktu yang agar tujuan pembelajaran dapat dicapai. Oleh karena itu, sangat penting bagi guru memikirkan media apa yang paling sesuai dengan materi yang akan disampaikannya.

Seorang guru juga harus mampu memilih strategi pembelajaran yang menarik agar tujuan dari pembelajaran dapat tercapai dengan baik. Untuk itu, penting bagi seorang guru memiliki kecakapan dalam memilih strategi pembelajran yang paling sesuai dengan bantuan media pembelajaran yang menarik sehingga terciptanya pembelajaran yang kooperatif.

Seni budaya dan prakarya (SBdP) merupakan salah satu muatan pembelajaran yang diajarkan di tingkat pendidikan SD, SMP dan SMA. Ruang lingkup materi pembelajaran seni budaya dan prakarya terdiri dari empat pokok materi seni rupa, seni musik, seni tari, dan seni drama. Idealnya, keempat materi yang ada pada mata pelajaran ini harus diajarkan pada siswa oleh guru kelas. Tetapi, berdasarkan wawancara pada observasi awal dengan guru kelas SD di Bengkulu Selatan Ibu Wantumarni (wawancara, 5 Maret 2020) bahwa kenyataan di lapangan guru kelas belum mampu mengajarkan muatan pembelajaran seni budaya dengan maksimal karena berbagai keterbatasan baik secara materi yang belum dikuasai guru maupun sarana dan prasarana yang ada di sekolah. Ironisnya, jam pembelajaran seni budaya dan prakarya pun acapkali tidak diberikan dan diganti dengan jam pembelajaran lainnya. Hal ini tentu saja menyebabkan kurang optimalnya pemberian materi pelajaran seni budaya dan prakarya pada peserta didik.

Kurang optimalnya pemberian materi pelajaran seni budaya dan prakarya terutama yang terjadi pada guru-guru di sekolah Yayasan Al Khair disebabkan oleh beberapa kendala yang terkait yaitu dilihat dari faktor guru, siswa dan sarana prasana sekolah. Pertama, jika dilihat dari faktor guru sebagai pendidik mengenai cara penyampaian muatan pembelajaran seni budaya dan prakarya tersebut apakah telah mengakomodir ketertarikan siswa, apakah sudah menerapkan pembelajaran kooperatif yang kreatif, dan apakah sudah menciptakan suasana yang menarik dan menyenangkan bagi siswa. Kedua, jika dilihat dari faktor siswa dapat dilihat dari minat anak terhadap metode pembelajaran seni yang didapatkannya. Kejadian ini kerap terjadi terutama bagi anak yang terlibat dalam pembelajaran seni baik seni musik, seni tari, seni drama, dan seni rupa secara aktif. Kemungkinan yang sering terjadi adalah anak merasa bosan karena ia tidak menemukan sesuatu yang menarik dan menyenangkan. Ketiga, dilihat dari sarana dan prasarana yang ada di sekolah yang belum terpenuhi guna membantu guru dalam menyampaikan materi pembelajaran seni budaya dan prakarya terutama sekolah-sekolah yang berada diberbagai pelosok daerah.

Selain ketiga faktor utama di atas, banyaknya materi pembelajaran seni budaya dan prakarya berupa seni rupa, seni musik, seni tari dan seni drama dengan alokasi waktu yang terbatas, turut menjadi masalah bagi guru-guru membagi waktu agar semua materi tersebut dapat disampaikan secara optimal. Oleh sebab itu, pembelajaran terpadu merupakan solusi yang tepat digunakan untuk menyampaikan materi pembelajaran seni. Maka dari itu, perlu kepiawaian seorang guru dalam memanajemen sebuah kelas menjadi faktor utama agar tercapainya tujuan pembelajaran. Sebab, guru merupakan kunci utama dalam menentukan strategi, metode, media dan segala sesuatu 
hal yang berkaitan tentang proses pembelajaran di kelas. Tujuan akhirnya berujung pada peningkatan semangat belajar peserta didik terhadap suatu muatan pembelajaran sehingga penyampaian materi yang ingin disampaikan dapat diterima dengan baik oleh siswa.

Berdasarkan fenomena yang terjadi di atas, penting sekali bagi seorang guru untuk selalu memperbaharui informasi tentang perkembangan ilmu pengetahuan dan teknologi yang baru. Guru harus berperan aktif mencari informasi terbaru terkait segala sesuatu yang berhubungan dengan pendidikan khususnya proses pembelajaran di kelas.

Untuk menjawab tantangan kemajuan pendidikan berbasis teknologi informasi ini, maka Universitas Terbuka telah menciptakan Forum ilmiah yang didedikasi bagi para guru dan semua orang yang memiliki perhatian kepada upaya peningkatan mutu pendidikan guru dan mutu pembelajaran di Sekolah berupa Portal Guru Pintar Online (GPO) yang dapat diakses melalui www.gurupintar.ut.ac.id Istilah kata pintar dalam Guru Pintar Online ini memiliki arti "Pintu Interaksi Antar Guru", dengan harapan bahwa media online ini bisa dijadikan sebagai sarana komunikasi interaktif dalam kerangka menumbuhkan budaya belajar sepanjang hayat.

Berkaitan dengan hal ini, tim abdimas dosen FKIP UT Bengkulu telah sepakat dengan ketua yayasan Al Khair yang dalam ini diwakilkan oleh kepala sekolah SDIT Al Qalam serta beberapa dewan guru dari yayasan Al Khair baik TK, SD dan SMP sebagai mitra dalam melaksanakan pelatihan dalam rangka optimalisasi penyampaian materi seni budaya dan prakarya melalui pembelajaran terpadu berbasis portal GPO. Pelatihan ini bertujuan untuk melihat bagaimana pengetahuan dan keikutsertaan guru dalam teknologi informasi guna pembelajaran seni di sekolah; bagaimana prakarya guru dalam mengakses informasi serta menentukan media pembelajaran berbasis teknologi; serta untuk mengetahui apakah pemberian materi pembelajaran seni oleh guru pada siswa dalam muatan pembelajaran seni budaya dan prakarya sudah optimal.

\section{METODE PELAKSANAAN}

\subsection{Pendekatan Kegiatan}

Untuk mencapai kegiatan pengabdian kepada masyarakat/abdimas dosen FKIP UT yang diajukan oleh UPBJJ UT Bengkulu pada guru-guru dari yayasan Al Khair Bengkulu Selatan, maka dilakukan melalui beberapa pendekatan sebagai berikut:

1. Model Participatory Rural Appraisal (PRA), yang menekankan keterlibatan guru-guru dalam keseluruhan kegiatan mulai dari perencanaan, pelaksanaan dan evaluasi program.

2. Model Community Development, yaitu dengan melibatkan guru-guru secara langsung sebagai subyek dan obyek pelaksanaan kegiatan pengabdian kepada masyarakat (PkM) Dosen.

3. Pendekatan persuasif, yaitu pendekatan yang bersifat himbauan dan dukungan tanpa unsur paksaan bagi guru-guru untuk berperan aktif.

4. Edukatif, yaitu pendekatan tim melalui sosialisasi, pelatihan dan pendampingan, dalam rangka saling bertukar pengetahuan dan pengalaman sebagai ciri bentuk pemberdayaan masyarakat.

Adapun jumlah orang yang dilibatkan dalam kegiatan ini dapat diuraikan sebagai berikut:

1. Satu (1) orang Ketua Yayasan Al Khair yang diwakilkan oleh Ibu Kepala Sekolah SDIT Al Qalam Bengkulu Selatan sekaligus sebagai pengurus Yayasan Al Khair

2. Tujuh Puluh (70) orang tenaga pengajar di Yayasan Al-Khair yang terdiri dari guru TK/ PAUD, guru SDIT, dan guru SMPIT

3. Dua (2) orang Mahasiswa aktif Prodi PGSD, FKIP, Universitas Terbuka Bengkulu 


\subsection{Teknis Pelaksanaan Kegiatan}

Program peningkatan pengetahuan dan keikutsertaan guru dalam teknologi informasi ini menggunakan pendekatan sosialisasi dan pelatihan terkait dengan peningkatan kapasitas. Program ini disusun dengan menggunakan metode pembelajaran orang dewasa, dimana tahapan pembelajaran meliputi:

a. Tahap penyampaian program, yang terdiri dari:

1) Pengertian, tujuan dan manfaat yang didapat dari kegiatan abdimas dosen UT Bengkulu.

2) Macam-macam program yang ditawarkan oleh abdimas dosen FKIP UT Bengkulu.

b. Tahap pelatihan, yang terbagi ke dalam dua bentuk jenis pelatihan berikut:

1) Pelatihan peningkatan pengetahuan dan keikutsertaan guru dalam teknologi informasi guna pembelajaran seni di sekolah

2) Pelatihan peningkatan prakarya guru dalam mengakses informasi serta menentukan media pembelajaran berbasis teknologi khususnya portal GPO

3) Pelatihan kemampuan pemberian materi pembelajaran seni budaya dan prakarya oleh guruguru sekolah

c. Tahap pendampingan, yang meliputi:

1) Sosialisasi tentang perkembangan teknologi informasi mengenai subyek pengabdian

2) Sosialisasi mengakses informasi serta menentukan media pembelajaran berbasis teknologi khususnya mengakses portal GPO

3) Pendampingan dalam menentukan strategi dan media pembelajaran yang tepat untuk menyampaikan materi pembelajaran seni budaya dan prakarya guru-guru di Bengkulu Selatan

Untuk mendapatkan apa yang menjadi tujuan dilakukannya PkM Dosen ini, maka perlu dilakukan pula kegiatan monitoring dan evaluasi (monev), dengan melakukan proses penggalian kemampuan peserta, baik sebelum dilakukannya pelatihan (pre-test) maupun pasca telah diberikannya pelatihan (post-test). Hal ini penting dilakukan, agar Tim PkM Dosen dapat mengidentifikasi keberhasilan dari program yang dilakukan ini.

\subsection{Partisipasi Mitra}

Kegiatan pengabdian ini akan berjalan baik, jika terjalinnya kerjasama yang baik antara pihak tim abdimas dosen FKIP UT Bengkulu dengan mitra, dimana abdimas dosen FKIP UT Bengkulu dalam menyukseskan kegiatan ini menyediakan tutor, materi pelatihan dan pendampingan. Sedangkan mitra dalam hal ini berasal dari tenaga pengajar di yayasan Al-Khair yang terdiri dari guru TK/ PAUD, guru SDIT, dan guru SMPIT di Bengkulu Selatan terutama guru yang mengajar muatan pembelajaran seni budaya dan prakarya yang bersedia mengikuti kegiatan pelatihan dan pendampingan dengan baik.

\subsection{Roadmap Kegiatan Abdimas Dosen FKIP UT Berbasis GPO}

Roadmap atau peta jalan dari kegiatan ini menghasilkan beberapa tahapan yang ingin dicapai (Gambar 1), sehingga tujuan dari pelaksanaan abdimas dosen FKIP UT ini mampu menjawab permasalahan mitra dengan baik dan terarah sesuai target capaian. 


\section{Gambar 1}

\section{Roadmap Kegiatan}

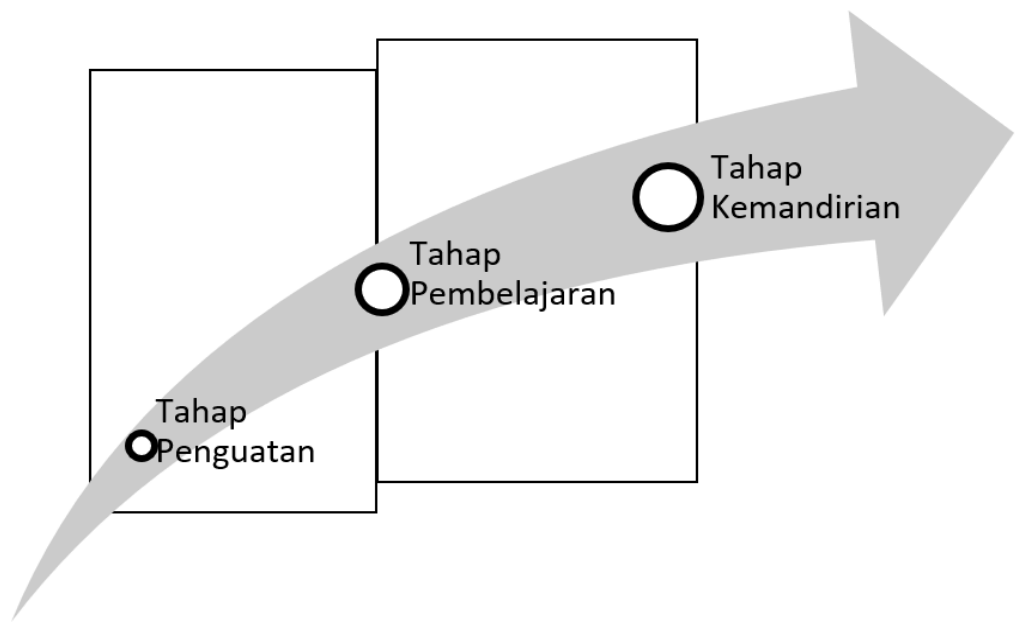

\section{HASIL DAN PEMBAHASAN}

\subsection{Persiapan Kegiatan Sosialisasi dan Pelatihan}

Persiapan kegiatan sosialisasi dan pelatihan ini dilakukan oleh tim abdimas agar pelaksanaan kegiatan berjalan sebagaimana mestinya sesuai dengan tujuan dari program ini. Persiapan dilakukan dengan cara memastikan segala kebutuhan yang berkaitan dengan pelatihan telah dipersiapkan dengan baik oleh guru-guru dari yayasan Al-Khair yang terdiri dari guru TKIT, SDIT dan SMPIT yang pelaksanaanya dilaksanakan di SDIT Al-Qalam.

Tahapan persiapan dilanjutkan dengan melengkapi seluruh administrasi yang dibutuhkan dalam usaha menyukseskan kegiatan sosialisasi dan pelatihan. Mulai dari mempersiapkan sarana kegiatan serta kemungkinan peserta yang akan menghadiri kegiatan tersebut. Persiapan alat-alat pendukung lainnya disiapkan oleh pihak sekolah yang sangat antusias menerima kedatangan tim abdimas Universitas Terbuka Bengkulu untuk melangsungkan kegiatan tersebut di SDIT AlQalam. Pihak yayasan mengarahkan seluruh tenaga pengajar untuk mengikuti kegiatan sosialisasi dengan tujuan mendapatkan ilmu tambahan dan pencerahan baru terkait inovasi pendidikan terkini. Menurut Ibu Rahmaniar Ulfa, S.Pd selaku kepala sekolah SDIT AL-Qalam sekaligus mewakili pihak yayasan mengatakan bahwa telah mengarahkan seluruh guru di bawah naungkan yayasan Al Khair untuk mengikuti kegiatan ini sebanyak lebih dari 100 orang guru. Akan tetapi, karena banyaknya guru yang berkewajiban untuk kunjungan ke sekolah siswa maka peserta sosialisasi dan pelatihan program abdimas dosen FKIP dihadiri sebanyak 70 (tujuh puluh) orang guru.

\subsection{Pelaksanaan Kegiatan Pelatihan}

Kegiatan pelatihan dilaksanakan selama dua hari yaitu pada hari kamis dan jumat tanggal 13 s/d 14 Agustus 2020 di ruang belajar SDIT Al-Qalam Yayasan Al-Khair Bengkulu Selatan. Pelaksanaan kegiatan hari pertama dimulai pada pukul 07.30 WIB hingga pukul 16.00 WIB; hari kedua dilaksanakan pada pukul 07.30 WIB hingga pukul 11.30 WIB yang telah diikuti oleh 70 orang guru yang mengajar di yayasan Al-Khair baik dari tingkat TK, SD maupun SMP. Adapun susunan acara pada kegiatan optimalisasi penyampaian materi seni budaya dan prakarya melalui pembelajaran terpadu berbasis GPO di Kabupaten Bengkulu Selatan dapat dilihat pada Tabel 1.

Pemberian materi sesuai dengan arahan berkenaan tentang "peningkatan pengetahuan dan keikutsertaan guru dalam teknologi informasi" merupakan salah satu cara meningkatkan 
profesionalisme guru. Keadaan di lapangan ditemukan bahwa lebih dari $50 \%$ guru-guru banyak yang tidak mengikuti perkembangan teknologi informasi ini. Terbukti saat pemberian materi dan pelatihan sebagian besar dari peserta kesulitan untuk mengakses portal GPO. Untuk itu, pelatihan ini merupakan salah satu solusi yang ditawarkan dalam memecahkan permasalahan yang ada terutama dalam hal meningkatkan pengetahuan dan keikutsertaan guru dalam teknologi informasi khususnya dalam pembelajaran seni di sekolah.

Setelah pemberian materi berkenaan teknologi informasi, para peserta dibimbing secara langsung mengakses beberapa informasi digital khususnya Guru Pintar Online yang dapat diakses melalui laman www.gurupintar.ut.ac.id Pada sesi ini, para peserta dibimbing dan dilatih untuk mengenal fitur-fitur yang ada di laman GPO seperti 1) Laboratorium Pendidikan, yang memuat microteaching online, penelitian tindakan kelas, materi pembelajaran, dan sekolah UT; 2) Program Diklat yang memuat program sertifikat, referensi hasil penelitian, dan sertifikat karya ilmiah guru; 3) Belajar Online yang memuat OER UT, BIPA UT, rujukan dikbud, rujukan umum; 4) Informasi GPO; 5) Survei dan Mahasiswa; dan 6) Forum Diskusi.

\section{Tabel 1}

\begin{tabular}{llll}
\multicolumn{2}{l}{ Susunan Acara } & & \\
\hline No & Kegiatan & Waktu & Pemandu \\
\hline Kamis, 13 Agustus 2020 & & \\
$\mathbf{1}$ & Registrasi Peserta & $08.00 \mathrm{~s} / \mathrm{d} 08.30$ & Mahasiswa UT \\
$\mathbf{2}$ & Pembukaan & $08.30 \mathrm{~s} / \mathrm{d} 09.00$ & Yayasan Al Khair \\
$\mathbf{3}$ & Sambutan Pihak Yayasan & $09.00 \mathrm{~s} / \mathrm{d} 09.30$ & Yayasan Al Khair \\
$\mathbf{4}$ & Peningkatan pengetahuan dan keikutsertaan guru dalam & $09.30 \mathrm{~s} / \mathrm{d} 11.00$ & Tim Abdimas \\
& teknologi informasi & & \\
$\mathbf{5}$ & Diskusi dan Tanya Jawab & $11.00 \mathrm{~s} / \mathrm{d} 11.45$ & Tim Abdimas \\
$\mathbf{6}$ & ISHOMA & $11.45 \mathrm{~s} / \mathrm{d} 13.00$ & \\
$\mathbf{7}$ & Pelatihan peningkatan prakarya guru dalam mengakses & $13.00 \mathrm{~s} / \mathrm{d} 14.30$ & Tim Abdimas \\
& informasi berbasis teknologi khususnya Portal GPO & & \\
$\mathbf{8}$ & Diskusi dan Tanya Jawab & $14.30 \mathrm{~s} / \mathrm{d} 15.15$ & Tim Abdimas \\
$\mathbf{J u m a t}$ & 14 Agustus 2020 & & \\
$\mathbf{1}$ & Registrasi Peserta & $08.00 \mathrm{~s} / \mathrm{d} 08.30$ & Mahasiswa UT \\
$\mathbf{2}$ & Pelatihan kemampuan pemberian materi pembelajaran seni & $08.30 \mathrm{~s} / \mathrm{d} 10.00$ & Tim Abdimas \\
& budaya dan prakarya & & \\
$\mathbf{3}$ & Diskusi Tanya Jawab & $10.00 \mathrm{~s} / \mathrm{d} 10.45$ & Tim Abdimas \\
$\mathbf{4}$ & Doa dan Penutup & $10.45 \mathrm{~s} / \mathrm{d} 11.30$ & Yayasan Al-Khair \\
\hline
\end{tabular}

Laboratorium pendidikan memuat berbagai informasi yang akan menjadi sumber inspirasi bagi upaya perbaikan mutu pendidikan secara berkelanjutan. Laboratorium pendidikan berisi informasi terkait regulasi dan perkembangan dalam bidang pendidikan, pengalaman praktek baik (best practices) dalam bidang pembelajaran, serta rujukan sumber dan media pembelajaran yang dapat diakses secara bebas oleh para guru dan pemerhati pendidikan. Perkembangan regulasi lebih menekankan pada varias informasi dan perkembangan seputar Kurikulum 2013. Sementara itu, praktek baik disajikan dalam bentuk video dan artikel-artikel pendidikan yang dapat menyajikan inspirasi bagi perbaikan mutu pendidikan (diakses pada laman gurupintar.ut.ac.id).

Sesuai dengan arahan pelatihan yaitu membimbing para peserta dapat mengakses dan mendaftar di berbagai situs terkait informasi tentang pendidikan yang salah satunya adalah Guru Pintar Online ini (GPO). GPO merupakan forum ilmiah yang dikelolah oleh FKIP Universitas Terbuka dan didedikasi bagi para guru dan semua pihak yang memiliki perhatian kepada upaya peningkatan mutu pendidikan guru dan mutu pembelajaran di Sekolah. Istilah kata pintar dalam Guru Pintar Online ini memiliki arti "Pintu Interaksi Antar Guru", dengan harapan bahwa media online ini 
bisa dijadikan sebagai sarana komunikasi interaktif dalam kerangka menumbuhkan budaya belajar sepanjang hayat. Portal Guru Pintar Online memberikan akses kepada guru dan pemerhati pendidikan guru untuk bersama-sama memberikan kontribusi bagi upaya peningkatan ilmu pengetahuan dan pengalaman praktik baik (Best Practices) dalam bidang pendidikan dan pembelajaran. Kontribusi dapat dilakukan melalui laman dalam GPO, khususnya melalui laboratorium pendidikan dan galeri profil. Selanjutnya, FKIP-UT, sebagai pengelola portal ini, berharap seluruh masyarakat pendidikan dapat memanfaatkan portal GPO sebagai sumber belajar dan sumber inspiratif bagi peningkatan profesionalisme guru secara berkelanjutan (diakses pada laman gurupintar.ut.ac.id).

GPO merupakan forum ilmiah yang dapat mempertemukan semua guru dan pemerhati pendidikan seluruh Indonesia dari berbagai pelosok bahkan sampai ke luar negeri secara online. Melalui GPO semua guru dan pemerhati pendidikan dapat saling berbagi pengalaman terkait pembelajaran di sekolah dengan baik berupa video micro-teaching, hasil penelitian tindakan kelas, materi pembelajaran bahkan berbagai hal terkait pengalaman di sekolah. Tidak hanya itu, setiap anggota guru dan pemerhati pendidikan juga dapat saling memberikan masukkan dan komentar serta bebagi pengalaman dengan mengakses laman dalam GPO yaitu forum diskusi dengan cara mendaftar sebagai anggota GPO.

Begitu banyak informasi dan pengalaman yang dapat diperoleh melalui portal GPO yang merupakan pintu interaksi antar guru dan menjangkau guru-guru yang berada dipelosok dan sulit terjangkau dengan tatap muka namun dapat dijangkau melalui portal GPO melalui jaringan internet. Terkait dengan pandemic covid 19 saat ini, portal GPO menjadi salah satu solusi agar semua guru tetap dapat melakukan interaksi dan saling bertukar informasi secara dalam jaringan. Dengan begitu tidak ada alasan bagi guru untuk tidak mendapatkan informasi terkait perkembangan pendidikan saat ini.

Sehubungan dengan pelatihan yang melatih para peserta mengakses informasi terkait teknologi khususnya portal GPO, pelatihan ini juga membimbing para peserta yang terdiri dari guru TK, SD dan SMP dari yayasan Al Khair Bengkulu Selatan agar dapat optimal dalam menyampaikan materi seni budaya dan prakarya. Pelatihan ini bertujuan agar pemberian materi SBdP dapat disampaikan dengan peserta didik secara maksimal sehingga apa yang menjadi tujuan pembelajaran yang dimuat dalam kurikulum dapat tercapai.

Selain itu, pelatihan ini telah mengedukasi para guru agar tidak menganggap mata pelajaran SBdP sebagai pelajaran yang tidak penting sehingga sering diabaikan. Keadaan ini terbukti saat tim abdimas ingin menyampaikan maksud dan tujuan dari pengabdian ini kepada pihak yayasan $\mathrm{Al}$ Khair sebagai usaha mengoptimalkan penyampaian materi pembelajaran seni budaya dan prakarya di sekolah sempat mendapat penolakan. Bukan hanya itu, pihak yayasan yang merupakan pimpinan dari sekolah-sekolah yang akan dijadikan mitra ini meminta tim abdimas untuk mengubah materinya menjadi mata pelajaran lain. Hal inilah yang menjadi dasar yang sangat kuat dari tim abdimas untuk bertekad ingin melaksanakan pelatihan sebagai bentuk upaya optimalisasi penyampaian materi seni budaya dan prakarya melalui pembelajaran terpadu berbasis portal GPO.

Muatan pembelajaran seni budaya dan prakarya ini terdiri dari berbagai cabang seni yaitu seni tari, seni musik, seni drama dan seni rupa. Keempat cabang seni ini idealnya dapat disampaikan pada peserta didik, walaupun dalam kurikulum 2013 guru dapat memilih salah satu dari keempat sabang seni tersebut. Namun, kembali mengingat bahwa setiap peserta didik itu berbeda-beda, maka sebaiknya seorang guru yang mengajar di suatu kelas tertentu dapat memberikan keempat materi tentang seni ini ke dalam satu konsep pembelajaran terpadu. 
Pembelajaran terpadu sesungguhnya sudah diatur sedemikian rupa dalam kurikulum 2013 melalui pembelajaran tematik. Akan tetapi, tidak semua guru piawai dalam menyampaikan materi tersebut dengan baik. Maka dari itu, melalui pelatihan ini tim abdimas yang berlatar belakang pendidikan seni drama, tari dan musik telah berbagi ilmu dengan para peserta dan mengubah pola pikir guru yang menyatakan bahwa pembelajaran seni di sekolah tidaklah penting dapat diubah. Menurut Rondhi (2017:11) mengatakan hal yang penting tentang pendidikan seni bagi siswa adalah siswa mampu mengekpresikan dirinya sebab mengekspresikan diri merupakan kebutuhan yang ada di dalam diri setiap orang dengan kata lain melalui seni siswa dapat mengungkapkan, menyatakan dan mengkomunikasikan pikiran, perasaan, atau emosinya pada orang lain.

Pentingnya pembelajaran seni harus diajarkan pada setiap anak di sekolah menjadi salah satu solusi agar minat dan bakatnya dapat diekspresikan dengan baik melalui pembelajaran di sekolah. Sebab, dewasa ini banyak sekali penyimpangan terjadi oleh para siswa salah satunya saat bermain aplikasi TikTok. Para siswa yang tidak terarah bakatnya di bidang seni sering melakukan perbuatan-perbuatan asusila karena bakat seninya tidak diarahkan dengan baik. Untuk itu, perlu adanya bimbingan dari guru di skeolah serta dukungan dari orangtua di rumah agar anak dapat mengekspresikan dirinya dalam kegiatan yang positif.

Berdasarkan pelatihan dan diskusi yang sudah dilakukan pada mitra guru-guru dari yayasan Al Khair dapat ditarik beberapa kesimpulan berkenaan mengapa pembelajaran seni sering diabaikan di sekolah, antara lain 1) guru tidak menguasai materi seni yaitu seni tari, seni musik, seni drama dan seni rupa; 2) kurangnya sarana dan prasarana yang ada di sekolah berkaitan pembelajaran seni; 3) Adanya tuntutan dari orangtua agar anak lebih cerdas dalam bidang mata pelajaran pokok seperti matematika, IPA dan bahasa inggris; dan 4) Pembelajaran seni termasuk pembelajaran yang tidak penting karena tidak diujiankan dalam ujian nasional. Berkaitan dengan alasan-alasan inilah, maka Guru Pintar Online (GPO) hadir sebagai media sarana komunikasi antar guru khususnya yang ada di seluruh pelosok Indonesia. Melalui GPO, guru-guru yang memiliki permasalahan yang disebutkan di atas dapat mengunjungi laman GPO khususnya laboratorium pendidikan yang memuat berbagai contoh video micro-teaching dan berbagai informasi lainnya dari para guru dan pemerhati pendidikan di laman dalam GPO bagian forum diskusi. Dengan demikian, besar harapan tim abdimas Dosen FKIP agar guru-guru dari yayasan Al Khair dapat meningkatkan pengetahuan dan keikutsertaannya terkait teknologi informasi, terampil mengakses informasi berbasis teknologi dalam hal ini adalah mengakses portal GPO, serta dapat mengoptimalkan kemampuannya memberikan materi pembelajaran seni budaya dan prakarya pada siswa.

\subsection{Evaluasi Kegiatan Sosialisasi}

Pelaksanan pelatihan berlangsung dengan lancar dan tertib, sesuai dengan harapan tim abdimas. Respon peserta terhadap materi sangat baik karena berkaitan langsung dengan dilema yang mereka rasakan berkaitan dengan materi pelajaran seni budaya dan prakarya. Permasalahan kesulitan dalam menyampaikan materi seni budaya dan prakarya tidak hanya dirasakan oleh guru sekolah dasar yang merupakan guru kelas, melainkan oleh guru SMP yang pada kenyataannya bukan ahli dibidang tersebut. Berdasarkan hasil kegiatan yang telah dilaksanakan, maka didapat evaluasi terkait pelaksanaan kegiatan.

Evaluasi yang pertama berkaitan dengan prakegiatan. Diawal penandatanganan kerjasama antara UT Bengkulu dan yayasan Al-Khair, pihak yayasan sempat meragukan materi sosialisasi berkaitan dengan mata pelajaran seni budaya dan prakarya. Hal tersebut berkaitan dengan citra mata 
pelajaran seni budaya dan prakarya yang pada fenomenanya banyak yang tidak sesuai dengan akhidah keislaman dan dirasa tidak penting untuk dipelajari, sedangkan mereka merupakan sekolah islam terpadu. Menyikapi hal tersebut tim abdimas mendeskripsikan dan memberikan ilustrasi berkaitan dengan pelaksanaan kegiatan yang akan dilakukan serta benang merah dari pelatihan ini yang akan diselaraskan dengan kebutuhan guru termasuk guru di sekolah islam terpadu.

Fakta dilapangan menyebutkan bahwa kesulitan-kesulitan para guru dalam menyampaikan materi seni budaya dan prakarya di setiap jenjang pendidikan merupakan alasan yang utama yang menyebabkan muatan pembelajaran ini sering diabaikan. Selain itu, materi seni budaya dan prakarya pada buku-buku sering tidak sesuai dengan seni budaya daerah setempat dan tak kalah penting pula yang selalu dirasakan oleh sekolah-sekolah islam terpadu bahwa terdapat kesenjangan materi terhadap aqidah islam yang menjadi panduan pembelajaran mereka. Melalui pelaksanaan pelatihan ini, guru-guru dari yayasan Al Khair yaitu guru TKIT Qurrata Ayyun, SDIT Al-Qalam, dan SMPIT Al Qalam merasa terbantu dalam hal membuka wawasan dan menemukan referensi cara mengajarkan mata pelajaran seni budaya dan prakarya pada peserta didik.

Evaluasi kedua, berkaitan dengan pelaksanaan kegiatan yang diikuti oleh guru-guru yang jumlahnya lebih dari 70 orang yang berarti dua kali lipat lebih banyak dari perkiraan awal membuat proses penyampaian materi dan pemateri lebih tertantang. Peserta pun tidak hanya berasal dari guru-guru SD, melainkan guru-guru dari TK dan SMP yang dipayungi oleh yayasan Al-Khair Bengkulu Selatan. Dengan latar belakang peserta yang berbeda-beda dari segi beban kerjanya, bidang keahlian, pendidikan dan lainnya tersebut membuat pembahasan diskusi materi semakin luas namun tetap pada ranah muatan tema penelitian.

Penyampaian materi berisikan latar belakang tema, pengenalan portal GPO, peran GPO dalam penyampaian materi seni budaya dan prakarya, fasilitas-fasilitas yang terdapat dalam GPO, dan langkah registrasi pada portal GPO. Secara runtun pemateri mengarahkan guru untuk memahami fasilitas yang terdapat dalam portal GPO, dengan tujuan agar para peserta pelatihan memahami manfaat dan mampu memanfaatkannya sebagai referensi dan fasilitas penambah ilmu pengetahuan mereka sebagai pendidik. Berdasarkan evaluasi berupa tugas dan angket kegiatan, dapat diketahui pemateri memberikan tugas kepada peserta untuk melakukan registrasi di portal GPO sesuai dengan langkah-langkah yang telah dipraktekkan saat materi berlangsung. Hasilnya $60 \%$ peserta yang mampu melakukan registrasi saat dilaksanakannya pelatihan di hari pertama yang ditunjukkan dengan screenshot bukti pendaftaran, selanjutnya $40 \%$ lainnya para peserta melaksanakan tugas tersebut diluar jam pelatihan. Sehingga, butuh bimbingan dan evaluasi lanjutan diluar kegiatan pelatihan pada para peserta pelatihan untuk bergabung sebagai anggota forum GPO sehingga dapat saling bertukar informasi terkait mata pelajaran yang ingin diketahui.

Dengan demikian, tujuan dari pelatihan ini dapat tercapat dengan baik berdasarkan bukti screenshot para peserta pelatihan yang berhasil mendaftarkan diri serta bergabung dalam forum diskusi portal GPO, bahkan sudah ada yang mengupload dan berbagi video pembelajaran dala portal tersebut. Berdasarkan hasil angket evaluasi yang disebarluaskan pada 70 peserta pelatihan, dapat disimpulkan bahwa para peserta (Guru dari Yayasan Al Khair) mampu meningkatkan pengetahuannya terkait teknologi informasi; peserta dapat mengakses informasi berbasis teknologi dalam hal ini telah mengakses Portal GPO dan mendaftarkan diri sebagai anggota forum diskusi Portal GPO melalui www.gurupintar.ut.ac.id yang dapat menambah wawasan, sekaligus menjadi sarana informasi dan komunikasi yang baru bagi para peserta pelatihan yaitu guru-guru dari Yayasan Al Khair untuk berbagi ilmu dan pengetahuan terkait pendidikan. 


\section{KESIMPULAN DAN SARAN}

\subsection{Kesimpulan}

Berdasarkan pelatihan yang sudah dilaksanakan maka dapat ditarik kesimpulan, bahwa;

1. Para peserta pelatihan telah mampu meningkatkan pengetahuannya terkait teknologi informasi.

2. Para peserta pelatihan telah dapat mengakses informasi berbasis teknologi dalam hal ini telah mengakses portal GPO dan mendaftarkan diri sebagai anggota forum diskusi portal GPO melalui www.gurupintar.ut.ac.id

3. Para peserta pelatihan dapat menambah wawasan dan mengoptimalkan kemampuannya memberikan materi pembelajaran seni budaya dan prakarya pada siswa melalui portal GPO sekaligus menjadi sarana informasi dan komunikasi yang baru bagi para peserta pelatihan yaitu guru-guru dari yayasan Al Khair untuk berbagi ilmu dan pengetahuan terkait pendidikan.

\subsection{Saran}

1. Guru berupaya meminimalisir kesalahan-kesalahan pada penyampaian materi pelajaran seni budaya dan prakarya dengan menemukan referensi dan melakukan diskusi pada portal GPO yang dapat diakses melalui www.gurupintar.ut.ac.id

2. Guru mampu mengembangkan materi Seni budaya dan prakarya berbasis kedaerahan dan sesuai dengan dunia anak dengan memanfaatkan portal GPO yang dapat diakses melalui www.gurupintar.ut.ac.id

\section{REFERENSI}

Arikunto, S. (2009). Dasar-dasar evaluasi pendidikan. Bumi Aksara.

Arsyad, A. (2011). Media pembelajaran. PT Raja Grafindo Persada.

Asesoria, P. D. (2013). Pengembangan multimedia interaktif pembelajaran musik di sd negeri 1 Gombong.

Asyhar, Rayandra. 2011. Kreatif mengembangkan media Pembelajaran. GP Press.

Binanto, B. (2010). Multimedia digital dasar teori dan pengembangan. CV Andi.

Darmawan, D. (2012). Pendidikan teknologi informasi dan komunikasi. PT. Remaja Rosdakarya.

Darmawan, D. (2014). Pengembangan e-learning teori dan desain. PT. Remaja.

Darmawan, D., \& Setiawati, L. (2015). Developing integrated management information system in research: A study at the institute for research and community services of universitas pendidikan Indonesia. International Journal of Applied Engineering Research, 10(16), 37206-37210.

Desyandri, D. (2014). Peran seni musik dalam pendidikan multikultural. Jurnal Pembangunan Pendidikan: Fondasi dan Aplikasi, 2(1), 1-11.

Majid, A. (2014). Strategi pembelajaran. Rosdakarya.

Nurdin, S., \& Andriantoni, A. (2016). Kurikulum dan pembelajaran. Raja Grafindo Persada.

Rusman, R. (2012). Model-model pembelajaran: Mengembangkan profesionalisme guru. Raja Grafindo Persada.

Rondhi, M. (2017). Apresiasi seni dalam konteks pendidikan seni. Imajinasi: Jurnal Seni, 11(1), 9-18. https://doi.org/10.15294/imajinasi.v11i1.11182.

Sihombing, L. B. (2011). Penerapan metode pembelajaran seni dan budaya berbasis multimedia untuk meningkatkan hasil belajar siswa. Generasi Kampus, 4(2).

Syamsuar, S., \& Reflianto, R. (2019). Pendidikan dan tantangan pembelajaran berbasis teknologi informasi di era revolusi industri 4.0. E-Tech: Jurnal Ilmiah Teknologi Pendidikan, 6(2). https://doi.org/10.24036/et.v2i2.101343.

Trilling, T., \& Fadel, F. (2009). 21st century skills: Learning for life in our times. Jossey Bass. 